\title{
Thermodynamic properties of water desorption in lettuce seeds
}

\section{Propriedades termodinâmicas da dessorção de água de sementes de alface}

\author{
Juliana Soares Zeymer ${ }^{1}$; Paulo Cesar Corrêa ${ }^{2}$; Gabriel Henrique Horta de Oliveira ${ }^{3}$; \\ Fernanda Machado Baptestini ${ }^{4 *}$
}

\begin{abstract}
Knowledge of the movement of water molecules inside material is important for the study of interactions between water and chemical components of agricultural products. The thermodynamic properties calculation reports this need, being the source of information to design drying equipment, calculate the energy required in this process and evaluate the physical phenomena that occur on the food surface. Given the importance of the subject, the objective of this study was to determine the thermodynamic properties of the water desorption process in lettuce seeds. Lettuce seeds had an initial moisture content of $9.3 \%$ (d.b.). The equilibrium moisture content of seeds was determined by static gravimetric method at different temperatures $\left(10,20,30,40\right.$ and $\left.50 \pm 1{ }^{\circ} \mathrm{C}\right)$ and relative humidity values (between 11 and $96 \%$ ). Experiments were conducted in triplicate. It was observed that, with increasing equilibrium moisture content, there was a reduction in the energy required for evaporation of water in lettuce seeds, with values of integral isosteric heat of desorption in the water content range 2.1 to $21.2 \%$ (d.b.) which varied from ' 4164.89 to 2477.43 ' $\mathrm{kJ} \mathrm{kg}^{-1}$. With increasing equilibrium moisture content there was a decrease in differential entropy, resulting in lower demand for mobility of water molecules. The Gibbs free energy also decreased with increasing equilibrium moisture content and was positive for all temperatures studied, showing non-spontaneity of water desorption in the seeds. The enthalpy-entropy compensation theory was has been satisfactorily applied to the sorption phenomenon and the water desorption process in lettuce seeds was controlled by enthalpy.
\end{abstract}

Key words: Differential enthalpy. Differential entropy. Enthalpy-entropy compensation theory. Equilibrium moisture content. Gibbs free energy. Isosteric heat.

\section{Resumo}

O conhecimento da movimentação das moléculas de água dentro do material é importante para o correto estudo das interações entre a água e os componentes químicos dos produtos agrícolas. O cálculo das propriedades termodinâmicas relata essa necessidade, sendo fonte de informação para projetar equipamentos de secagem, calcular a energia requerida nesse processo e avaliar os fenômenos físicos que ocorrem na superfície dos alimentos. Diante da importância do assunto, o objetivo do presente trabalho foi determinar as propriedades termodinâmicas do processo de dessorção de água em sementes de alface. As sementes de alface possuíam teor de água inicial de 9,3\% (b.s.). O teor de água de

\footnotetext{
${ }^{1}$ Discente de Doutorado, Programa de Pós-Graduação em Engenharia Agrícola, Departamento de Engenharia Agrícola, Universidade Federal de Viçosa, UFV, Viçosa, MG, Brasil. E-mail: juliana.zeymer@ufv.br

2 Prof. Dr., Departamento de Engenharia Agrícola, UFV, Viçosa, MG, Brasil. E-mail: copace@ufv.br

3 Prof. Dr., Instituto Federal de Educação, Ciência e Tecnologia Sudeste de Minas Gerais, IF Sudeste MG, Campus Manhuaçu, Distrito Realeza, Manhuaçu-MG, Brasil. E-mail: gabriel.oliveira@ifsudestemg.edu.br

4 Prof. Dra ${ }^{\text {a }}$ Departamento de Engenharia Rural, Universidade Federal do Espírito Santo, UFES, Campus de Alegre, Alegre, ES, Brasil. E-mail: fbaptestini@yahoo.com.br

* Author for correspondence
} 
equilíbrio das sementes foi determinado pelo método estático-gravimétrico para diferentes valores de temperatura $\left(10,20,30,40\right.$ e $50 \pm 1{ }^{\circ} \mathrm{C}$ ) e atividade de água (entre 11 e $96 \%$ ), em três repetições. De acordo com os resultados encontrados, observou-se que com o aumento do teor de água de equilíbrio, ocorre redução da energia necessária para a evaporação da água nas sementes de alface, sendo que os valores do calor isostérico integral de dessorção, na faixa de teor de água de 2,1 a 21,2\% (b.s.), variaram de 4164,89 a $2477,43 \mathrm{~kJ} \mathrm{~kg}^{-1}$. Com a elevação do teor de água de equilíbrio, há um decréscimo da entropia diferencial, implicando em menor demanda de mobilidade das moléculas de água. A energia livre de Gibbs também diminuiu com o incremento do teor de água de equilíbrio, sendo positiva para todas as temperaturas estudadas, demonstrando a não espontaneidade do processo de dessorção de água nas sementes. A teoria da compensação entalpia-entropia foi satisfatoriamente aplicada ao fenômeno de sorção, sendo o processo de dessorção de água das sementes de alface controlado pela entalpia.

Palavras-chave: Entalpia diferencial. Entropia diferencial. Teoria da compensação entalpia-entropia. Equilíbrio higroscópico. Energia livre de Gibbs. Calor isostérico.

\section{Introduction}

Cultivation of lettuce (Lactuca sativa L.) is of large economic importance in Brazil, occupying second place in the production area used for leafy vegetables (ALBUQUERQUE et al., 2010). It is grown in almost all regions of the world, justifying the development of research to increase productivity and, consequently, profit for producers.

The lettuce seed embryo, called the achene, is surrounded by endosperm which can delay or prevent seed germination by acting as a physical barrier to radicle protrusion, especially under unfavorable conditions, such as high temperatures (NASCIMENTO; CANTLIFFE, 2002). Due to this, lettuce seeds require suitable post-harvest technologies for their optimum preservation.

According to Oliveira et al. (2015), drying is one of the most well-known and used technologies in the world for ensuring the quality and stability of fresh products during shelf-life. Reduction in the moisture content of material by drying reduces biological activity and chemical or physical changes during the post-harvest procedures and until final consumption.

Knowledge of thermodynamic processes involved in drying agricultural products is important for designing drying equipment, studying the properties of adsorbed water, calculating the energy required in the process, evaluating the microstructure of food and studying the physical phenomena occurring on the food surface (CORREA et al., 2010). Thys et al. (2010) reported that some thermodynamic properties are used in the analysis of sorption behavior and in biological systems, including the isosteric heat of sorption, entropy and enthalpy differential and compensation theory calculated from sorption isotherms.

Enthalpy changes provide a measure of energy change occurring during the interaction of water molecules with product constituents during the sorption processes. Entropy can be associated with binding of water molecules to or their repulsion from food components in the system and is associated with the spatial arrangement of the water-product relationship. relationship waterproduct. Thus, according to Oliveira et al. (2011), entropy characterizes the degree of order or disorder existing in the water-product system. Gibbs free energy is indicative of the product's affinity with water, providing a criterion for evaluating water desorption. Changes in Gibbs free energy during water exchange between the product and the surroundings are associated with the energy required to transfer water molecules from the vapor state to a solid surface or reciprocally.

Shape and size of seeds are important parameters that should be determined in order to study different processes, such as hygroscopic equilibrium. Several studies were performed to determine the 
thermodynamic parameters of different seeds, similar in shape and size to lettuce seeds, such as grape seed (Vitis sp) (MAJD et al., 2014), turnip seed (Brassica rapa subsp. rapa) (SOUSA et al., 2015), cucumber seed (Cucumis sativus L.) (CORRÊA et al., 2015) and pepper seed (Capsicum sp) (SILVA et al., 2016).

Therefore, even though there is a considerable wealth of literature about thermodynamic properties, information in the thermodynamic properties of lettuce seeds is still emerging. Thus, the objective of this study was to obtain and evaluate the thermodynamic properties (integral isosteric heat of sorption, differential entropy, Gibbs free energy and enthalpy-entropy compensation theory) of lettuce seeds in different conditions of temperature and hygroscopic equilibrium moisture content.

\section{Materials and Methods}

Lettuce seeds (Lactuca sativa L.) with an initial moisture content of $9.3 \%$ (d.b.) were acquired from the experimental area at the Fitotecnia Department of the Federal University of Viçosa - MG, Brazil. Seeds were then transported to the Laboratory of Physical Properties and Quality of Agricultural Products at the Federal University of Viçosa, Viçosa, MG, Brazil. The seeds were benefited and packed in polyethylene bags and stored in a camera type B.O.D. (model $347 \mathrm{CD} /$ brand Fanem) at a temperature of $5{ }^{\circ} \mathrm{C}$ until analysis.

The static gravimetric method was used to obtain the equilibrium moisture content of lettuce seeds by the desorption process (BRASIL, 2009) in different temperatures $(10,20,30,40$ and $50 \pm 1$ ${ }^{\circ} \mathrm{C}$ ) and relative humidity conditions (between 11 and $96 \%$ ), until the product reached the equilibrium moisture content of the specified air condition. The temperatures used were controlled by a camera B.O.D. and the relative humidity was provided by saturated salt solutions. Each sample consisted of $20 \mathrm{~g}$ of seed with three replications.
During the process, samples were weighed periodically on an analytical balance (model AY220/ brand Marte) and hygroscopic equilibrium was reached when the mass value remained unchanged for three consecutive weighings. Moisture content of the product was then determined by the gravimetric method using an oven with forced air circulation at $105 \pm 1{ }^{\circ} \mathrm{C}$ for $24 \mathrm{~h}$ in triplicate, according to Brasil (2009). The experimental design was completely randomized with five levels of temperature $(10,20$, 30,40 , and $50^{\circ} \mathrm{C}$ ), eight levels of relative humidity $(0.1,0.3,0.4,0.5,0.6,0.7,0.8$ and 0.9 decimal d.b.) and three replicates.

Mathematical models often used to predict the hygroscopicity of agricultural products were adjusted to the experimental data of equilibrium moisture content of lettuce seeds. The model chosen to determine the thermodynamic properties of lettuce seeds was the Modified Oswin model (IGUAZ; VÍRSEDA, 2007) as this showed the best fit to the experimental data, with a determination coefficient of $98.88 \%$, magnitude of mean relative error of $8.02 \%$ (d.b.), standard deviation of the estimate of $0.55 \%$ (d.b.) and random distribution of residue. With this model, water activity values were obtained using Equation 1:

$X e=\left(9.579071 * *_{-} 0.088723 * * \times T\right)\left[\frac{a_{w}}{1-a_{w}}\right]^{\frac{1}{3.230984 *}}$

** Significant at $1 \%$ using the $\mathrm{t}$-test

In which $\mathrm{Xe}$ is equilibrium moisture content (\% d.b), $\mathrm{a}_{\mathrm{w}}$ is water activity (decimal) and $\mathrm{T}$ is temperature $\left({ }^{\circ} \mathrm{C}\right)$.

Thermodynamic parameters, such as entropy of desorption $(\Delta S)$, differential enthalpy $(\Delta H)$, Gibbs free energy $(\Delta G)$ and enthalpy-entropy relationship, were obtained using the methodology described by Corrêa et al. (2012), in which an approximate $(1-\alpha) 100 \%$ confidence interval for isokinetic temperature was used. These parameters 
are expressed by Equations 2 to 6, respectively. The + and - symbols in Equation 2 and others related to thermodynamic properties indicate the direction of heat transfer, which is associated with the spontaneity of the process studied. Thus, a negative sign corresponds to the desorption processes in the present study. Values of $\Delta \mathrm{S}, \Delta \mathrm{H}$ and $\Delta \mathrm{G}$ were submitted to regression analysis.

$$
\begin{aligned}
& \ln a_{w}= \pm\left(\frac{\Delta H_{s t}}{R T}-\frac{\Delta S}{R}\right) \\
& \Delta H=\Delta H_{s t}+\Delta H_{v a p} \\
& \Delta G= \pm R T \ln a_{w} \\
& T_{B}=\hat{T}_{B} \pm t_{m-2, \alpha / 2} \sqrt{V_{a r}}\left(T_{B}\right) \\
& T_{h m}=\frac{n_{t}}{\sum_{i=1}^{n_{t}}\left(\frac{1}{T_{i}}\right)}
\end{aligned}
$$

In which $\mathrm{H}$ is isosteric heat of sorption $\left(\mathrm{kJ} \mathrm{kg}^{-1}\right)$, $\Delta \mathrm{H}_{\text {vap }}$ is latent heat of vaporization of pure water $\left(\mathrm{kJ} \mathrm{kg}^{-1}\right), \Delta \mathrm{H}_{\mathrm{st}}$ is net isosteric heat of sorption $(\mathrm{kJ}$ $\left.\mathrm{kg}^{-1}\right), \Delta \mathrm{S}$ is differential entropy of sorption $\left(\mathrm{kJ} \mathrm{kg}^{-1}\right.$ $\left.{ }^{\mathrm{K}-1}\right), \Delta \mathrm{G}$ is Gibbs free energy $\left(\mathrm{kJ} \mathrm{kg}^{-1} \mathrm{~mol}-1\right), \mathrm{T}_{\mathrm{B}}$ is isokinetic temperature $(\mathrm{K}), \mathrm{T}_{\mathrm{hm}}$ is harmonic mean temperature $(\mathrm{K}), \mathrm{n}_{\mathrm{t}}$ : number of temperatures utilized (dimensionless).

\section{Results and Discussion}

The water activity data estimated by the Modified Oswin model (Equation 1) with temperatures of $10,20,30,40$ and $50{ }^{\circ} \mathrm{C}$ and equilibrium moisture content between 2.1 and $21.2 \%$ (d.b.) are shown in Table 1. These data were used to determine the values of enthalpy and entropy differential of desorption in lettuce seeds. It was observed that, with increasing equilibrium moisture content, there was an increase in water activity and the same effect was observed with increasing temperature.

The values of integral isosteric heat of sorption integral isosteric heat in lettuce seeds as a function of equilibrium moisture content varied from
'4164.89 to 2477.43 ' $\mathrm{kJ} \mathrm{kg}^{-1}$ for moisture content range 2.1 to $21.2 \%$ (d.b.), as can be seen in Figure 1. Increase in energy released by water sorption in the product was observed with reduced equilibrium moisture content; this is explained by differences in the water binding forces with the sorbent surface of a given product. According to Al-Muhtaseb et al. (2004), in early stages of sorption (low moisture content), polar sorption sites are highly active, of high energy interaction, in the sorbent surface, which are covered with water molecules, forming a monomolecular layer. While water molecules bind chemically to highly active sorption sites, sorption occurs in less active sites (high moisture content) with less interaction energy and, consequently, lower isosteric heat of sorption (WANG; BRENNAN, 1991).

Similar results to the sorption process in lettuce seeds were found by Sousa et al. (2015), studying the thermodynamic properties of water desorption in turnip seeds. These authors found that the values of integral isosteric heat of desorption in the moisture content range 3.33 to $11.30 \%$ (d.b.) ranged from ' 4222.70 to $2870.34{ }^{\prime} \mathrm{kJ} \mathrm{kg}^{-1}$. According to McMinn and Magee (2003), the magnitude of isosteric heat of sorption can be explained by biological stability and physical and chemical features that each species presents under given storage conditions.

The differential entropy of desorption was strongly related to the moisture content of lettuce seeds, with values of ' 4.15 to $0.14{ }^{~ '} \mathrm{~kJ} \mathrm{~kg}^{-1}$ when equilibrium moisture content was in the range 2.1 to 21.2\% (d.b.), as shown in Figure 2. It was observed that, with the increase in moisture content, there was a decrease in the differential entropy, showing a similar tendency to that observed for values of integral isosteric heat of sorption. This behavior was related to the mobility of water molecules present during the desorption process. With high water activity, there are fewer available places for connection between the molecules, resulting in lower demand for mobility of water molecules (GONELI et al., 2010). 
Table 1. Water activity values $\left(\mathrm{a}_{\mathrm{w}}\right)$, estimated using the Modified Oswin model, as a function of temperature $\left({ }^{\circ} \mathrm{C}\right)$ and equilibrium moisture content $(\mathrm{Xe})$ in lettuce seeds.

\begin{tabular}{cccccc}
\hline \multicolumn{5}{c}{ Water activity $($ decimal $)$} \\
\hline Xe (\% d.b.) & \multicolumn{5}{c}{ Temperature $\left({ }^{\circ} \mathrm{C}\right)$} \\
\cline { 2 - 6 } & 10 & 20 & 30 & 40 & 50 \\
\hline 2.10 & 0.0101 & 0.0142 & 0.0208 & 0.0320 & 0.0525 \\
2.60 & 0.0199 & 0.0279 & 0.0406 & 0.0619 & 0.0994 \\
3.50 & 0.0503 & 0.0697 & 0.0996 & 0.1471 & 0.2238 \\
4.20 & 0.0871 & 0.1190 & 0.1663 & 0.2371 & 0.3420 \\
4.70 & 0.1206 & 0.1627 & 0.2229 & 0.3089 & 0.4278 \\
5.20 & 0.1598 & 0.2122 & 0.2845 & 0.3826 & 0.5089 \\
5.80 & 0.2130 & 0.2771 & 0.3614 & 0.4686 & 0.5959 \\
6.50 & 0.2811 & 0.3564 & 0.4499 & 0.5603 & 0.6806 \\
6.60 & 0.2912 & 0.3678 & 0.4621 & 0.5724 & 0.6912 \\
7.70 & 0.4034 & 0.4891 & 0.5857 & 0.6878 & 0.7865 \\
7.90 & 0.4234 & 0.5098 & 0.6057 & 0.7053 & 0.8001 \\
8.20 & 0.4531 & 0.5398 & 0.6340 & 0.7297 & 0.8187 \\
9.30 & 0.5544 & 0.6379 & 0.7224 & 0.8022 & 0.8715 \\
9.90 & 0.6036 & 0.6832 & 0.7610 & 0.8323 & 0.8924 \\
10.00 & 0.6113 & 0.6902 & 0.7669 & 0.8368 & 0.8955 \\
11.60 & 0.7176 & 0.7825 & 0.8416 & 0.8922 & 0.9326 \\
12.60 & 0.7685 & 0.8246 & 0.8741 & 0.9154 & 0.9476 \\
13.70 & 0.8131 & 0.8603 & 0.9010 & 0.9341 & 0.9595 \\
14.10 & 0.8268 & 0.8711 & 0.9090 & 0.9396 & 0.9630 \\
16.40 & 0.8861 & 0.9168 & 0.9421 & 0.9620 & 0.9770 \\
18.30 & 0.9172 & 0.9401 & 0.9586 & 0.9731 & 0.9837 \\
21.20 & 0.9469 & 0.9619 & 0.9739 & 0.9831 & 0.9898 \\
\hline & & \multicolumn{5}{c}{} \\
\hline
\end{tabular}


Figure 1. Observed and estimated values of integral isosteric heat of desorption $(\Delta \mathrm{H})$ as a function of equilibrium moisture content $\left(\mathrm{X}_{\mathrm{e}}\right) . * *$ Significant at $1 \%$ using the $\mathrm{t}$-test.

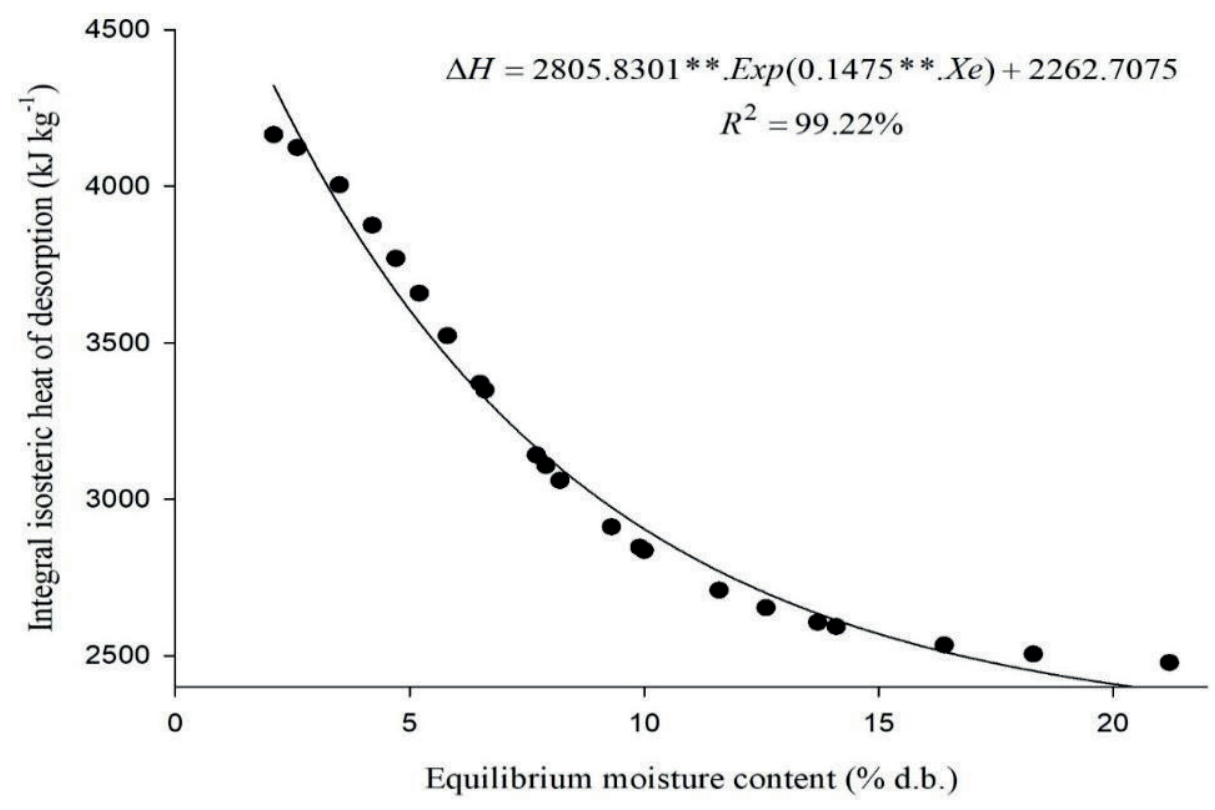

Figure 2. Observed and estimated values of the differential entropy $(\Delta \mathrm{S})$ as a function of equilibrium moisture content $\left(\mathrm{X}_{\mathrm{e}}\right) . * *$ Significant at $1 \%$ using the t-test.

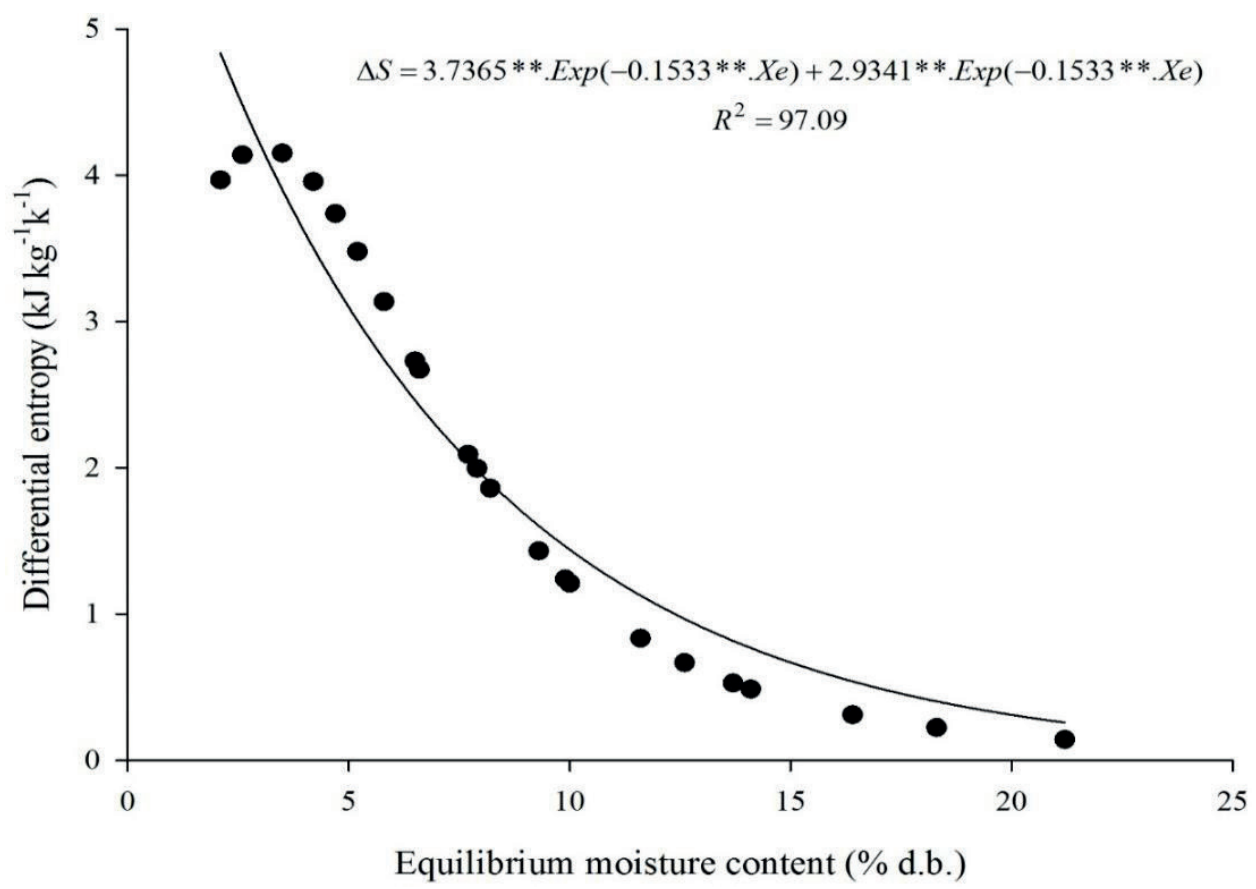


Oliveira etal.(2010), studying the thermodynamic properties of two sweet corn cultivars, found a range of differential entropy values similar to those found in this study ' 2.49 to 0.73 ' $\mathrm{kJ} \mathrm{kg}^{-1} \mathrm{~K}^{-1}$ and ' 3.01 to $0.55^{\prime} \mathrm{kJ} \mathrm{kg}^{-1} \mathrm{~K}^{-1}$ for sweet corn, BR 402, and super sweet corn, BR 400, respectively). However, it can be seen from Figure 2, that the behavior exhibited by differential entropy of lettuce seeds was nonlinear, unlike the linearity displayed by corn cultivars. This discrepancy can be explained by the water activity range studied in this investigation (0.01 to 0.98$)$, in contrast to the water activity range studied by other authors $(0.3$ to 0.6$)$.

It was observed that Gibbs free energy decreased with increasing of equilibrium moisture content, being positive for all temperatures studied and tending to stabilize at higher levels of equilibrium moisture content, as shown in Figure 3.

The Gibbs free energy of a product, from a thermodynamic point of view, is a parameter indicative of the affinity with food and water, it provides information about the spontaneity $(<0)$ or non-spontaneity $(>0)$ of sorption (McMINN et al., 2005). Furthermore, Nkolo Meze'e et al. (2008) reported that the Gibbs free energy is related to the work needed to make sorption sites available. Positive values of Gibbs free energy are characteristic of an exogenous reaction, in other words a reaction that requires an external agent to provide energy to the environment. These positive values were expected, once that desorption is not a spontaneous process, whereas the product is initially with higher moisture content, and subsequently subjected to psychrometric conditions of the air, that do lose water until equilibrium is reached.

As presented in Figure 3, it was also noted that Gibbs free energy decreases with increasing temperature due to the higher excitation of molecules that make up the product, accelerating gas exchange and, therefore, making the process faster and spontaneous. However, the influence of temperature on high values of moisture content becomes irrelevant since, at these levels, sorption sites are available (GONELI et al., 2013).

Figure 3. Gibbs free energy as a function of the equilibrium moisture content $\left(X_{e}\right)$ in lettuce seeds.

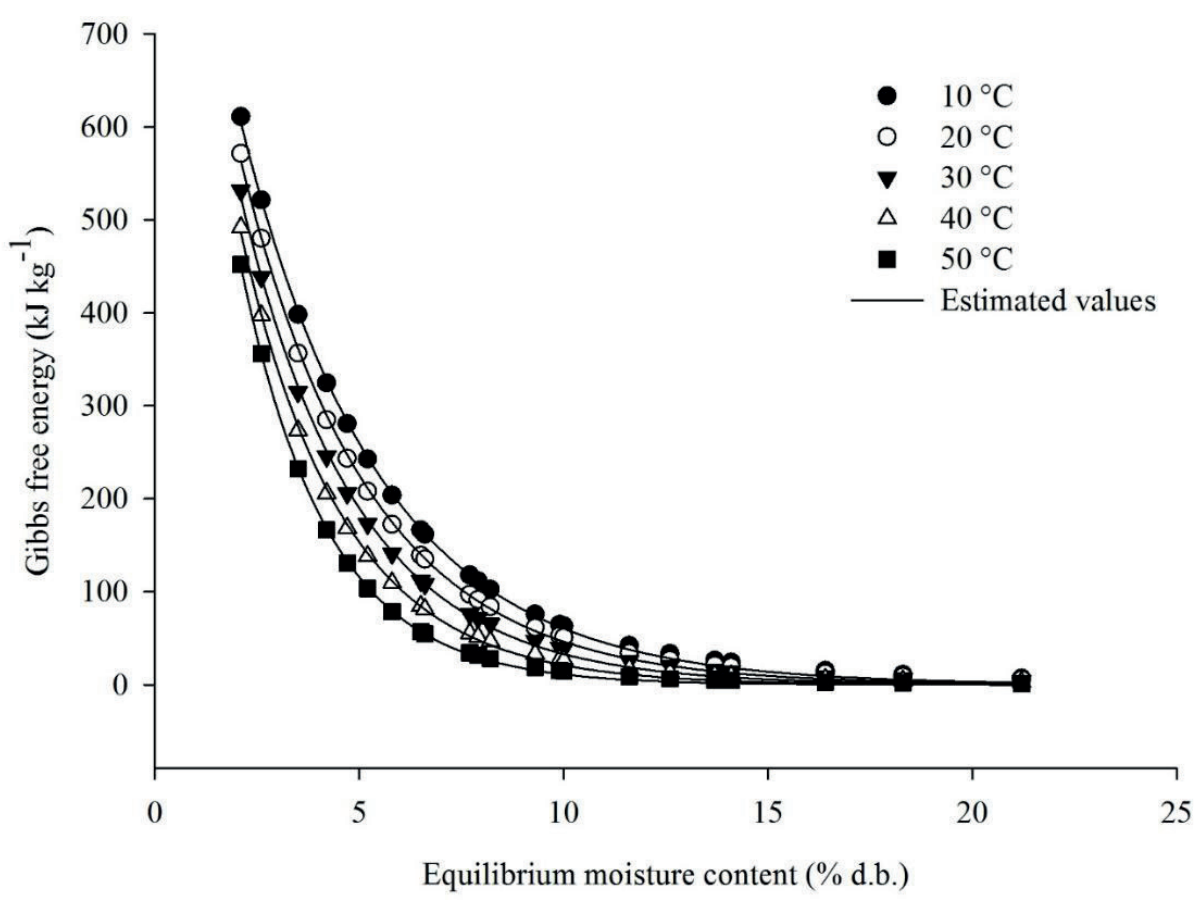

Semina: Ciências Agrárias, Londrina, v. 39, n. 3, p. 921-932, maio/jun. 2018 
As shown in Table 2, satisfactory values for the determination coefficient $\left(\mathrm{R}^{2}\right)$ were noted, indicating that there was good correspondence between observed data and data estimated using the proposed equations to predict values for Gibbs free energy. Furthermore, regression parameters were significant at $1 \%$ using the $\mathrm{t}$-test at all temperatures studied, showing an increase along with temperature increase.

Table 2. Regression equations fitted to the experimental values of Gibbs free energy in lettuce seeds at different temperatures, as a function of the equilibrium moisture content $\left(\mathrm{X}_{\mathrm{e}}\right)$, with their respective determination coefficients $\left(\mathrm{R}^{2}\right)$.

\begin{tabular}{ccc}
\hline Temperature $\left({ }^{\circ} \mathrm{C}\right)$ & Equation & $\mathrm{R}^{2}(\%)$ \\
\hline 10 & $\Delta \mathrm{G}=1115.3896 * \cdot \operatorname{Exp}(-0.29174 * * \cdot \mathrm{Xe})$ & 99.98 \\
20 & $\Delta \mathrm{G}=1094.4783 * * \cdot \operatorname{Exp}(-0.3163 * * \cdot \mathrm{Xe})$ & 99.96 \\
30 & $\Delta \mathrm{G}=1092.4140 * * \cdot \operatorname{Exp}(-0.3502 * * \cdot \mathrm{Xe})$ & 99.94 \\
40 & $\Delta \mathrm{G}=1121.7518 * * \cdot \operatorname{Exp}(-0.3983 * * \cdot \mathrm{Xe})$ & 99.95 \\
50 & $\Delta \mathrm{G}=1206.7587 * * \operatorname{Exp}(-0.4694 * * \cdot \mathrm{Xe})$ & 99.98 \\
\hline
\end{tabular}

** Significant at $1 \%$ using the t-test.

A strong correlation was observed between the two thermodynamic properties indicated by the linearity of the graph with a high coefficient of determination (98.23\%) (Figure 4). The high $\mathrm{R}^{2}$ value indicates that the enthalpy-entropy compensation theory is valid. However, only the difference between the harmonic mean temperature $\left(\mathrm{T}_{\mathrm{hm}}\right)$ and the isokinetic temperature $\left(\mathrm{T}_{\mathrm{B}}\right)$ may indicate that such a relationship exists (enthalpyentropy compensation theory). The isokinetic temperature for desorption in lettuce seeds was
389.64 K, whilst the mean harmonic temperature was $302.50 \mathrm{~K}$, being significantly different from the isokinetic temperature values reported, thereby confirming a linear chemically-based compensation effect. This theory permits verification of whether there will be a greater molecular interaction due to the decrease in the number of links or molecules of the system, generating larger organization or order (related to the enthalpy) about the disorganization and, consequently, greater freedom of molecules in the system (related to the entropy) (SPADA et al., 2013). 
Figure 4. Relationship between differential enthalpy and differential entropy of sorption. ** Significant at $1 \%$ using the t-test.

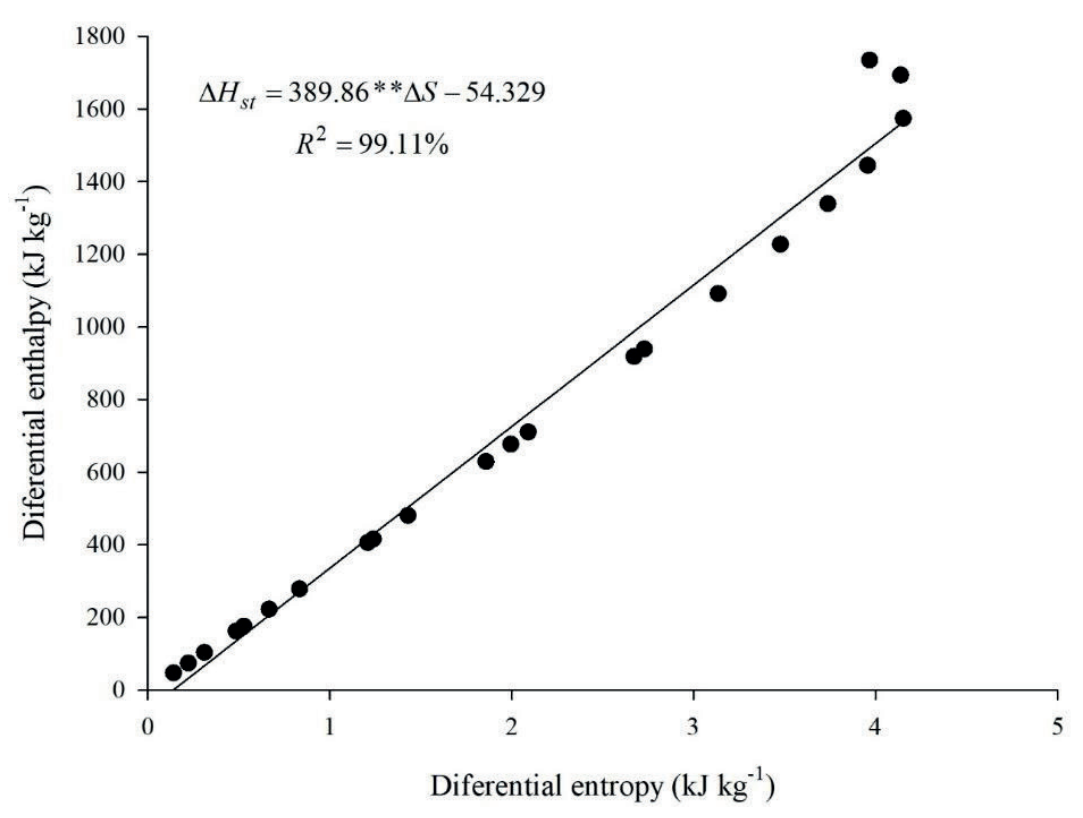

As the enthalpy-entropy compensation theory is valid for the desorption process in lettuce seeds, this process can be controlled by enthalpy or entropy. According to Corrêa et al. (2012), the process is controlled by enthalpy if $T_{B}>T_{h m}$ and is controlled by entropy if $T_{B}<T_{h m}$. Thus, moisture sorption in lettuce seeds is controlled by enthalpy. Applying the compensation theory implies that only one reaction mechanism is followed by all members of the reactive series, and the existence of a single mechanism suggests that the food microstructure is stable and does not undergo any change during moisture sorption (McMINN et al., 2005). These results are in agreement with several researchers who have applied the isokinetic theory to sorption in several products, concluding that the sorption phenomenon is controlled by enthalpy (CLADERA-OLIVEIRA et al., 2008; GONELI et al., 2013, 2016; MARTINEZ-MONTEAGUDO; SALAIS-FIERRO, 2014; MOREIRA et al., 2008; NICOLETI et al., 2015; SILVA et al., 2015; VEGAGÁLVEZ et al., 2014; TUNÇ; DUMAN, 2007).

\section{Conclusion}

Integral isosteric heat of desorption increases with decreasing equilibrium moisture content, indicating an increment of energy is required to remove moisture from the product. Differential entropy also increases with decreasing equilibrium moisture content, whilst Gibbs free energy decreases, being positive, indicating that desorption in lettuce seeds is a non-spontaneous process. The enthalpy-entropy compensation theory is valid for the desorption process in lettuce seeds, being enthalpy controlled.

\section{Acknowledgements}

The authors thank CAPES for the scholarship. 


\section{References}

ALBUQUERQUE, K. A. D.; ALVIM, P. O.; SILVA, P. A.; VEIGA, A. D. Qualidade fisiológica e bioquímica de sementes de alface revestidas com micronutrientes, aminoácidos e reguladores de crescimento. Bioscience Journal, Uberlândia, v. 26, n. 6, p. 843-848, 2010.

AL-MUHTASEB, A. H.; McMINN, W. A. M.; MAGEE, T. R. A. Water sorption isotherms of starch powders. Part 2: Thermodynamic characteristics. Journal of Food Engineering, Londres, v. 62, n. 2, p. 135-142, 2004.

BRASIL. Ministério da Agricultura e Reforma Agrária. Secretaria Nacional de Defesa Agropecuária. Regras para análises de sementes. Brasília: MAPA, 2009. 395 p.

CLADERA-OLIVEIRA, F.; PETTERMANN, A.; NOREÑA, C.; WADA, K.; MARCZAK, L. Thermodynamic properties of moisture desorption of raw pinhão (Araucaria angustifolia seeds). International Journal of Food Science and Technology, Oxford, v. 43, n. 5, p. 900-907, 2008.

CORRÊA, P. C.; OLIVEIRA, G. H. H.; BOTELHO, F. M.; GONELI, A. L. D.; CARVALHO, F. M. Modelagem matemática e determinação das propriedades termodinâmicas do café (Coffea arábica L.) durante o processo de secagem. Revista Ceres, Viçosa, MG, v. 57, n. 5, p. 595-601, 2010.

CORRÊA, P. C.; OLIVEIRA, G. H. H.; SANTOS, E. $\mathrm{S}$. Thermodynamic properties of agricultural products processes. In: ARANA, I. (Org.). Physical properties of foods: novel measurement techniques and applications. Boca Raton: CRC Press, 2012. p. 131-141.

CORREAA, P. C.; REIS, M. F. T.; OLIVEIRA, G. H. H.; OLIVEIRA, A. P. L. R.; BOTELHO, F. M. Moisture desorption isotherms of cucumber seeds: modeling and thermodynamic properties. Journal of Food Science, Londrina, v. 37, n. 3, p. 828-838, 2015.

GONELI, A. L. D.; CORREAA, P. C.; OLIVEIRA, G. H. H.; AFONSO JÚNIOR, P. C. Water sorption properties of coffee fruits, pulped and green coffee. LWT - Food Science and Technology, Zurique, v. 50, n. 2, p. 386-391, 2013.

GONELI, A. L. D.; CORRÊA, P. C.; OLIVEIRA, G. H. H.; GOMES, C. F.; BOTELHO, F. M. Water sorption isotherms and thermodynamic properties of pearl millet grain. International Journal of Food Science and Technology, Oxford, v. 45, n. 4, p. 828$838,2010$.

GONELI, A. L. D.; CORRÊA, P. C.; OLIVEIRA, G. H. H.; OLIVEIRA, A.P. L. R.; ORLANDO, R. C. Moisture sorption isotherms of castor beans. Part
2: Thermodynamic properties. Revista Brasileira de Engenharia Agrícola e Ambiental, Campina Grande, v. 20, n. 8, p. 757-762, 2016.

IGUAZ, A.; VÍRSEDA, P. Moisture desorption isotherms of rough rice at high temperatures. Journal of Food Engineering, Londres, v. 79, n. 3, p. 794-802, 2007.

MAJD, K. M.; KARPARVARFARD, S. H.; FARAHNAKY, A.; ANSARI, S. Thermodynamic properties of water sorption isotherms of grape seeds. International Agrophysics, Lublin, v. 8, n. 1, p. 63-71, 2014.

MARTINEZ-MONTEAGUDO, S. I.; SALAIS-FIERRO, F. Moisture sorption isotherms and thermodynamic properties of mexican mennonite-style cheese. Journal of Food Science and Technology, Karnataka, v. 51, n. 10, p. 2393-2403, 2014.

McMINN, W. A. M.; AL-MUHTASEB, A. H.; MAGEE, T. R. A. Enthalpy-entropy compensation in sorption phenomena of starch materials. Food Research International, Ontário, v. 38, n. 5, p. 505-510, 2005.

McMINN, W. A. M.; MAGEE, T. R. A. Thermodynamic properties of moisture sorption of potato. Journal of Food Engineering, Londres, v. 60, n. 2, p. 155-157, 2003.

MOREIRA, R.; CHENLO, F.; TORRES, M. D.; VALLEJO, N. Thermodynamic analysis of experimental sorption isotherms of loquat and quince fruits. Journal of Food Engineering, Londres, v. 88, n. 4, p. 514-521, 2008.

NASCIMENTO, W. M.; CANTLIFFE, D. J. Germinação de sementes de alface sob altas temperaturas. Horticultura Brasileira, Vitória da Conquista, v. 20, n. 1, p. 103-106, 2002.

NICOLETI, J. F.; ALVES, T. P.; FÓZ, H. D. Isotermas de dessorção de pimentão verde e energia envolvida no processo. Brazilian Journal of Food Technology, Campinas, v. 18, n. 2, p. 137-145, 2015.

NKOLO MEZE'E, Y. N.; NOAH NGAMVENG, J.; BARDET, S. Effect of enthalpy-entropy compensation during sorption of water vapour in tropical woods: the case of Bubinga (Guibourtia Tessmanii J. Léonard; G. Pellegriniana J. L.). Thermochimica Acta, Amsterdã, v. 468, n. 1-2, p. 1-5, 2008.

OLIVEIRA, G. H. H.; ARAGÃO, D. M. S.; OLIVEIRA, A. P. L.; SILVA, M. G.; GUSMÃO, A. C. A. Modelagem e propriedades termodinâmicas na secagem de morangos. Brazilian Journal of Food Technology, Campinas, v. 18, n. 4, p. 314-321, 2015.

OLIVEIRA, G. H. H.; CORRÊA, P. C.; ARAÚJO, E. F.; VALENTE, D. S. M.; BOTELHO, F. M. Desorption isotherms and thermodynamic properties of sweet corn 
cultivars (Zea mays L.). International Journal of Food Science and Technology, Oxford, v. 45, n. 3, p. 546-554, 2010.

OLIVEIRA, G. H. H.; CORRÊA, P. C.; SANTOS, E. S.; TRETO, P. C.; DINIZ, M. D. M. S. Evaluation of thermodynamic properties using $\mathrm{GAB}$ model to describe the desorption process of cocoa beans. International Journal of Food Science and Technology, Oxford, v. 46, n. 10, p. 2077-2084, 2011.

SILVA, C. L. O. C.; FARIA, L. J. G.; COSTA, C. M. L. Comportamento higroscópico de partes aéreas de pimenta-de-macaco (Piper aduncum L.). Revista Brasileira de Engenharia Agrícola e Ambiental, Campina Grande, v. 19, n. 4, p. 376-381, 2015.

SILVA, H. W.; COSTA, L. M.; RESENDE, O.; OLIVEIRA, D. E. C.; SOARES, R. S.; VALE, L. S. R. Thermodynamic properties of pepper seeds - variety Cabacinha. Revista Cientifica, Jaboticabal, v. 44, n. 2, p. 14-22, 2016.

SOUSA, K. A.; RESENDE, O.; GONELI, A. D. L.; SMANIOTTO, T. A. S.; OLIVEIRA, D. E. C. Thermodynamic properties of water desorption of forage turnip seeds. Acta Scientiarum Agronomy, Maringá, v. 37, n. 1, p. 11-19, 2015.
SPADA, J. C.; NOREÑA, C. P. Z.; MARCZAK, L. D. F.; TESSARO, I. C. Water adsorption isotherms of microcapsules with hydrolyzed pinhão (Araucaria angustifolia seeds) starch as wall material. Journal of Food Engineering, Londres, v. 114, n. 1, p. 64-69, 2013.

THYS, R. C. S.; NOREÑA, C. P. Z.; MARCZAK, L. D. F.; AIRES, A. G.; CLADERA-OLIVEIRA, F. Adsorption isotherms of pinhão (Araucaria angustifolia seeds) starch and thermodynamic analysis. Journal of Food Engineering, Londres, v. 100, n. 3, p. 468-473, 2010.

TUNÇ, S.; DUMAN, O. Thermodynamic properties and moisture adsorption isotherms of cottonseed protein isolate and different forms of cottonseeds samples. Journal of Food Engineering, Londres, v. 81, n. 1, p. 133-143, 2007.

VEGA-GÁLVEZ, A.; LÓPEZ, J.; AH-HEN, K.; TORRES, M. J.; LEMUS-MONDACA, R. Thermodynamic properties, sorption isotherms and glass transition temperature of cape gooseberry (Physalis peruviana L.). Food Technology and Biotechnology, Zagreb, v. 52, n. 1, p. 83-92, 2014.

WANG, N.; BRENNAN, J. G. Moisture sorption isotherm characteristics of potato at four temperatures. Journal of Food Engineering, Londres, v. 14, n. 4, p. 269-287, 1991. 
